\title{
Analysis of the Management of Facilities and Infrastructure at the Language Laboratory of the Manado State University
}

\author{
Delli Sabudu \\ Universitas Negeri Manado \\ delli.sabudu@gmail.com \\ Deitje A. Katuuk \\ Universitas Negeri Manado \\ deitjekatuuk@unima.ac.id \\ Viktory N.J. Rotty \\ Universitas Negeri Manado \\ viktoryrotty@unima.ac.id \\ Jeffry S.J. Lengkong \\ Universitas Negeri Manado \\ jeffrylengkong@unima.ac.id
}

\begin{abstract}
The purpose of this study was to determine the management of language laboratory infrastructure facilities, Language and Arts Faculty, Manado State University. This research is a qualitative descriptive study. Sources of research data are heads of laboratories and lecturers of subjects who use language laboratories. Data collection techniques using interview techniques, observation and documentation study. The data analysis technique used descriptive qualitative data analysis. The results showed that: 1) The need for language laboratory infrastructure has been prepared annually according to the needs; 2 ) the provision of language laboratory facilities and infrastructure has not been running optimally; 3) The use of language laboratory facilities has been running quite well. 4) inventory of language laboratory infrastructure has been carried out properly, in accordance with existing standard procedures; 5) the maintenance of language laboratory facilities has not run optimally due to the lack of laboratory assistants, resulting in less than optimal maintenance of laboratory facilities; 6) the elimination of language laboratory infrastructure facilities has been carried out in accordance with existing standard procedures.
\end{abstract}

Keywords: Management of Facilities and Infrastructure, Language Laboratory, Mainanance

Abstrak: Tujuan dari penelitian ini untuk mengetahui managemen sarana prasarana laboratorium Bahasa Fakultas Bahasa dan Seni Universitas Negeri Manado. Penelitian ini merupakan penelitian deskriptif kualitatif. Sumber data penelitian adalah para kepala laboratorium dan dosen mata kuliah yang menggunakan laboratorium Bahasa. Teknik pengumpulan data menggunakan teknik wawancara, observasi dan studi dokumentasi. Teknik analisis data menggunakan analisis data deskriptif kualitatif. Hasil penelitian menunjukkan bahwa: 1) Kebutuban sarana prasarana laboratorium bahasa sudah disusun perencananya setiap tabun sesuai dengan kebutuban.; 2) Pengadaan sarana dan prasarana laboratorium bahasa belum berjalan dengan maksimal; 3) Penggunaan sarana laboratorium bahasa sudah berjalan dengan cukup baik. 4) Inventarisasi sarana prasarana laboratorium bahasa sudah dilaksanakan 
dengan baik, sesuai dengan standart prosedur yang ada; 5) Pemeliharaan sarana prasarana laboratorium bahasa belum berjalan secara maksimal disebabkan oleh kurangnya tenaga laboran sehingga mengakibatkan pemeliharaan sarana laboratorium kurang optimal; 6) Penghapusan sarana prasarana laboratorium bahasa sudah dilaksanakan sesuai standart prosedur yang ada.

Kata Kunci: Manajemen Sarana dan Prasarana,, Laboratorium Bahasa, Pemeliharaan

\section{INTRODUCTION}

Educational infrastructure includes all tools or facilities that support the educational process. These infrastructure facilities include an educational building, tables, chairs, blackboards, a library building along with supporting books, including a laboratory building complete with supporting facilities for laboratory use. Means are anything that can facilitate the implementation of certain activities (Arikunto, 1987:6). Means also have the meaning of everything that can facilitate and expedite the implementation of all efforts. Meanwhile, laboratory facilities are all facilities needed in the teaching and learning process, both mobile and immobile so that the achievement of laboratory goals can run smoothly, regularly, effectively and efficiently. Furthermore, according to Umar Suwito in B. Suryosubroto, (2004:115) laboratory facilities are facilities that are used as intermediaries in the teaching and learning process, to further enhance the effectiveness and efficiency in achieving educational goals. Laboratory facilities are all facilities needed in the teaching and learning process, both mobile and immobile so that the achievement of educational goals can run smoothly, orderly, effectively and efficiently. In line with what was stated by $\mathrm{M}$ Hafyzh, Chaniago, Anisah, and Ermita.

"Adequate facilities in learning such as chairs, tables, blackboards, textbooks and learning media must be provided as needed. If there are no or inadequate educational facilities, the learning process will not run effectively and efficiently. Without supporting educational facilities, the education and learning process cannot run as it should. Therefore, the facilities or facilities need to be provided as needed. If the facility has been established, it must be utilized through an optimal process." (2020).

This makes clear how important the role of laboratory facilities and infrastructure is in achieving optimal teaching and learning.

Laboratory facilities include all equipment and supplies that are directly used in the teaching and learning process in the laboratory. Example: laboratory buildings, rooms, tables, chairs, laboratory equipment. Meanwhile, infrastructure is all components that indirectly support the teaching and learning process or education in a school (Zakaria, 2006). According to Ibrahim Bafadal (2003: 2), 
educational facilities are all equipment, materials and furniture that are directly used in the educational process in schools.

The language laboratory is a system that has a purpose. The language laboratory is part of the system for revitalizing higher education governance, especially in supporting the language learning process at the university level. This is motivated by the existence of several higher education institutions that have not optimally used laboratory facilities even though the buildings and supporting facilities are already available. Moreover, there are still many university members who have laboratories that do not really understand the important role of language laboratories and how to maintain good language laboratories, so that laboratory rooms and facilities are not in good condition and cannot support the lecture process optimally. The problems can be grouped according to the duties of the head of the laboratory, so that they are the substance of the duties of the head of the laboratory. Among them are tasks that are grouped into substance laboratory equipment.

Language laboratory facilities and infrastructure are one that is indispensable to support the improvement of the quality of the learning process in the Language and Arts faculty for Language Departments and Study Programs through practicum activities.

The Language Laboratory of the Language and Arts Faculty does not have sufficient facilities and infrastructure that can assist in the implementation of the language learning process. This is indicated by the large number of inadequate facilities and infrastructure. With complete laboratory facilities and infrastructure, laboratory managers hope to be able to use them optimally to support the smooth teaching and learning process. In the end, it is hoped that the quality of student learning can improve.

The success of the language learning program is strongly influenced by several factors, namely students, curriculum, educational staff, funds, laboratory infrastructure and facilities, and other environmental factors. If these factors are of good quality, and the quality language learning process will in turn produce quality graduates.

Lecturers are one of the actors in activities in the laboratory, especially those who teach subjects related to language skills, namely listening and speaking. Therefore, he is required to know his place of work. An understanding of what happens in the learning process will help them a lot to facilitate their duties as direct managers of the teaching and learning process. Lecturers need to understand the direct and indirect factors that support the teaching and learning process. For language lecturers, an understanding of the management of facilities and infrastructure will help broaden insights on how they can play a 
role in planning, using, and evaluating existing infrastructure and facilities so that these infrastructure and facilities can be used optimally to achieve educational goals.

An understanding of the administration of curriculum development will be very helpful in translating the curriculum into student learning experiences; an understanding of student administration will greatly assist them in carrying out the task of processing these students into high quality graduates; an understanding of the management of personnel or employees will assist their personal and professional development efforts; an understanding of the intricacies of financial administration will help lecturers to prioritize the implementation of their duties, because in the end the funds to support their activities are also limited; An understanding of the relationship between the campus and the community will help lecturers in their efforts to make the campus an inseparable part of society, so that there is good cooperation between the two.

Based on the author's observations about the skill standards obtained by students, one of which is due to the incomplete and incomplete management of facilities and infrastructure, this raises the question, is the management of language laboratory facilities and infrastructure at the Faculty of Language and Arts effective in accordance with national education standards? In order to get in-depth information about the management of language laboratory facilities and infrastructure, it is necessary to conduct research and the most appropriate is descriptive evaluative research in the Language and Arts faculty to find out more deeply the extent to which the management of the language laboratory facilities and infrastructure of the Language and Arts faculty is in accordance with the standards issued by the Ministry of Education and Culture.

\section{RESEARCH METHODS}

This research is a qualitative descriptive study. Qualitative descriptive research is research that has a tendency to approach it according to the actual situation. The consideration in choosing this approach is based on the fact that the data to be collected is data related to how the development of the language laboratory is structured, this information is directly collected from the manager of the Language laboratory at the Faculty of Language and Arts, State University of Manado. The subjects of this research are the Head of the Laboratory, the Dean in charge of facilities and infrastructure, language laboratory managers (laboratory heads, laboratory assistants and technicians), lecturers at the Language and Arts Faculty of Manado State University. In data collection, the techniques used are interviews, observation and documentation. Because of the 
qualitative method used, of course the data analysis was carried out qualitatively, namely by describing each research result which includes:

Program planning carried out by the Language Laboratory staff, Faculty of Language and Arts, Manado State University. The implementation of the language laboratory program at the Faculty of Language and Arts, Manado State University, has it been running according to the program planning that has been made or not. Evaluation of laboratory program activities, and the performance results of the language laboratory personnel of the Language and Arts Faculty, Manado State University.

In the process of analyzing the data in this study, the interactive analysis model used by Miles and Huberman (1987:21-25) was used. The data collected in the field is then presented in narrative form. Furthermore, the results of data collection are reduced and then summarized so as to find the main themes that are relevant to the research. During the data collection process the researcher has simultaneously reduced and presented data, both of which are components of data analysis. After this process, it is followed by making conclusions. Usually the first conclusions are initially still vague and doubtful so further action is needed, with increasing data the conclusions will become accurate.

\section{RESULTS AND DISCUSSION}

OECD (2001) explained Excellence in educational facilities lies not only in the quality of conception and construction, but also in the quality of management. In other words, how complete and good the available facilities are, all depend on the quality of the management of facilities and infrastructure.

After all data collection processes have been completed, the data processing is immediately carried out. Data regarding the management of laboratory facilities including planning, procurement, use, inventory, maintenance, and deletion were obtained from interviews. This interview guide consists of 25 questions which in practice can develop in accordance with the research objectives to further complement the information needed in the management of laboratory infrastructure. Meanwhile, for data obtained from the results of questionnaires and observations by researchers, the management of language laboratory facilities and infrastructure is used to support and complement the results of the analysis of the data obtained from the interview. The following will present research matters that will be used to answer the problem formulations above. Planning is the initial campus activity in designing the needs needed at the beginning of each new academic year. In planning, there is procurement, after the draft has been approved by the Chancellor and members of the regular meeting, the next step is procurement. 
Procurement is the process of providing the needs of both schools and colleges in accordance with the plans that have been made. According to Ibrahim Bafadal (2004: 26) planning is a process of thinking and determining activities or programs that will be carried out in the future to achieve certain goals. Planning for laboratory tools/materials has several components that need to be considered, namely when selecting tools/materials, procurement of tools/materials, analysis of needs, priority scale of tools/materials, accuracy in selecting tools/materials and suitability of funds. It can be obtained information that the Faculty of Language and Arts, State University of Manado often conducts procurement planning and selection of laboratory equipment/materials itself. This is in accordance with the statement of the laboratory manager, the results of the interview with the lecturer, which stated that: Planning for the procurement of laboratory facilities is carried out by the head of the laboratory. After that the plan is submitted to the Dean for approval, for the funding for the provision of language laboratory facilities the Faculty has provided special funds.

Based on the results of inventory observations about laboratory facilities found in the Language and Arts Faculty of the Manado State University, it shows that the equipment is still incomplete. This is because the problem of funds owned by the Faculty of Language and Arts, Manado State University and laboratory assistance from the local government has not been fulfilled. Another thing that becomes an obstacle is the limited administrative staff or laboratory assistants so that inventory is rarely done anymore in the faculty language laboratory. Furthermore, according to Ibrahim Bafadal (2004: 56) inventory is the recording of all state property. But actually what needs to be inventoried is not only that, all goods or equipment in educational institutions both schools and universities, both consumable and non-consumable goods, both stateowned goods and institutions owned either moving or immovable must be inventoried. in an orderly manner according to applicable standard procedures. In the procurement process, the managers and heads of study program laboratories and jurusan conduct deliberations to determine the facilities and infrastructure that will be provided as needed. This is done to determine the infrastructure needed for the language laboratory based on the recommendations of the heads of the Language laboratory in the department and study program. The suggestions of the head of the Language laboratory in the department and study program are of course based on the existing curriculum guidelines. After the procurement of the infrastructure is approved by the Dean as the head of the faculty, then the faculty treasury will collect data on the budget that will be spent. The procurement cost budget is taken from the Faculty PNBP fund. In addition to the faculty holding its own procurement, 
every year the faculty submits proposals to the university level to obtain additional funds. Other aspects include needs analysis, priority scale, and suitability of funds. The faculty has its own budget for the purchase of laboratory facilities, the funds come from PNBP. This is in accordance with the statement of the laboratory manager; purchasing equipment can choose a good price and quality according to the funds in the budget, because funds are very limited, the laboratory tools and materials in the Language Laboratory of the Faculty of Language and Arts, Manado State University are also available. Limited provided. Who is involved in planning the procurement and selection of language laboratory facilities for the Language and Arts Faculty, Manado State University? Namely the Dean, Laboratory Managers both Faculties, Departments and Prodi as well as lecturers who use the Language Laboratory. From the interviews conducted, it is known that before procuring laboratory infrastructure facilities, laboratory managers and all lecturers who use the language laboratory conduct a deliberation first, from the results of the recommendations of the heads of the Language Laboratory majors and study programs as well as the lecturers, then the laboratory manager makes a proposal.

Procurement of laboratory infrastructure, which is then submitted to the Dean for approval. The next step carried out by the laboratory manager is the detailing of the budget for procurement costs, if the funds are sufficient, the Faculty can immediately organize its own laboratory facilities. This is known from the results of interviews with laboratory managers, which state that: Planning is carried out by laboratory managers involving all heads of the Language laboratory in the department and study program as well as lecturers who use the language laboratory, then submit a proposal to the Dean, after the Dean approves the proposal then to the faculty treasurer to apply for funds, for planning laboratory facilities, the faculty already has its own funds. The results of the interview were confirmed by the lecturer, who stated that: planning for the procurement of laboratory facilities was discussed in advance by the head of the laboratory by involving all laboratory heads in the department and study program. From the results of the interview, it can be concluded that in planning the provision of language laboratory infrastructure at the Faculty of Language and Arts, State University of Manado, it involves laboratory managers, both Faculties, Departments and Prodi and all lecturers who use language laboratories, then the procurement of laboratory facilities is based on suggestions from the results of deliberations adjusted to the funds owned by the Faculty. Based on the results of the interview, it was strengthened by documentation in the form of an inventory of laboratory facilities. In the inventory, it can be seen that the Faculty does not yet have complete laboratory facilities, in other words it is still very limited. Accuracy in the selection of tools 
and materials and planning of usage schedules, clarified by the selection of tools/materials according to price, good quality, and the materials used in the manufacture of the tools must be in accordance with SNI standards while planning a laboratory use schedule at the Faculty of Language and Arts, State University Manado is not yet optimal. This is because the department and study program have many parallel classes so that they must be used alternately. In planning the usage schedule, the manager conducts deliberations with all lecturers who use the language laboratory. This is done to distribute the laboratory use schedule according to the course schedule. This is known from the results of interviews with laboratory managers, which state that: "laboratory use planning schedules are carried out in consultation with lecturers for courses using language laboratories, so that their use can run smoothly even though they are still very limited. This is reinforced by the results of interviews with course lecturers, which state that: "All lecturers of courses who use language laboratories are involved in planning laboratory use schedules, so that their use does not conflict with other classes that will use the laboratory. From the results of the interview, it was also strengthened by the observation results of the laboratory use schedule which includes the day, hour, and class that will use the laboratory. From the results of interviews and observations, it can be concluded that all lecturers using the language laboratory and laboratory managers plan schedules for laboratory use by way of deliberation. In planning the use of the laboratory, it includes the days, hours and classes that will use the laboratory. The conclusion from the laboratory infrastructure facility planning activities above, it is revealed that planning the procurement of laboratory infrastructure facilities at the Faculty

The Language and Arts of Manado State University is carried out by deliberation by the laboratory manager by involving all lecturers of subjects who use the language laboratory; Procurement of laboratory facilities based on the curriculum used at the Faculty of Language and Arts, Manado State University; The process of procuring laboratory facilities based on the recommendations of the heads of department and study program laboratories in the Language and Arts faculty, which was then approved by the Dean by adjusting the funds held by the Faculty; The laboratory management schedule planning process is carried out jointly by the laboratory manager.

\section{CONCLUSION}

Management of language laboratory facilities and infrastructure at the faculty of language and arts, Manado State University has not been fully implemented in accordance with the applicable language laboratory facility and infrastructure management standards. This condition is mainly seen in the limited number of supporting facilities in the language laboratory, only 20 units 
of computers for students, the lab room does not have air conditioner so that when the activity takes place the temperature in the room increases. There are still no storage cabinets for laboratory equipment and lockers for students to put bags in. In addition, the maintenance function of infrastructure is also very limited. Where the faculty have tried optimally to carry out the maintenance process as well as possible, but the results are still not optimal as expected. Likewise with the deletion function, language laboratories at all for various reasons have not carried out the maximum elimination of goods so that the management burden of language laboratory facilities becomes heavier because they still have to manage items that should have been destroyed. The condition of language laboratory facility management is influenced by many things, including: (1) The manager of the language laboratory facility does not yet have sufficient competency knowledge and skills to carry out their duties and responsibilities. (2) The head of the laboratory as the main person in charge of the management of language laboratory facilities has not been able to provide adequate time to schedule the use of the laboratory due to the limited facilities available. (3) Faculty finances, especially the budget for language laboratories, are very limited and the ability to raise funds from outside is still relatively limited, so it still relies heavily on funds from the government. (4) Culture and high awareness to maintain all goods of the facilities owned by the language laboratory have not grown and developed optimally.

\section{REFERENCE}

Apriana, D., Kristiawan, M., \&Wardiah, D. (2019). Headmaster's Competency In Preparing Vocational School Students For Entrepreneurship. International Journal of Scientific \& Technology Research, 8(8).

Arikunto, Suharsimi. (1987). Dasar-Dasar Administrasi Pendidikan. Yogyakarta: FIP IKIP Yogyakarta.

Ary H. Gunawan.(1996). Administrasi Sekolah. Jakarta: Rineka Cipta.

Bafadal, I \& Imron, A. (2004). Manajemen Peningkatan Mutu Berbasis Sekolah. Malang: Kerjasama FIP UM dan Ditjen Dikdasmen.

Bafadal, Ibrahim. (2005). Manajemen Pendidikan Mutu Sekolah. Jakarta. Bumi Aksara.

Barrett, Peter \& Baldry, David. (2004). Facilities Management Towards Best Practice. 2nd Edition. Oxford: Blackwell Science Ltd.

ChaniagoM. H., Anisah, and Ermita.(2020). "Pengelolaan Sarana Pendidikan Di Sekolah Menengah Kejuruan Negeri Di Kota Padang."Jurnal Bahana Manajemen Pendidikan 9(1):28-32

Fathurrochman, I. (2017). Implementasi Manajemen Kurikulum Dalam Upaya Meningkatkan Mutu Santri Pondok Pesantren Hidayatullah/Panti Asuhan Anak Soleh Curup [Implementation Of Curriculum 
Management An Effort To Improve The Quality Of Hidayatullah Islamic Boarding School]. Tadbir: Jurnal Studi Manajemen Pendidikan, 1(1), 85-104.

Fathurrochman, I. (2017). Pengembangan kompetensi pegawai aparatur sipil negara (ASN) Sekolah Tinggi Agama Islam Negeri (STAIN) Curup [The development of the competency of the state civil servant (ASN) STAIN Curup]. Manajer Pendidikan, 11(21), 120-129.

Fathurrochman, I., Budiman, D. A., Alamsyahril, \& Kristiawan, M. (2019). Revitalization Management Of Islamic Boarding School Preventing The Radicalism. Restaurant Business, (10), 495-505. Retrieved from https://journals.eduindex.org/index.php/rb/article/view/9462.

Harpani.(2009). Manajemen Sarana Prasarana Pendidikan pada SMA Negeri Kabupaten Muko-Muko. Tesis tidak diterbitkan. MMP Unib.

Herawan, E. \& Nasihin, S. (2002). Pengelolaan Sarana dan Prasarana Pendidikan. Bandung: Jurusan Administrasi Pendidikan FIP UPI.

Imam Tobroni, S. R., Pelana, R., Sianipar, G., Guefara, R. L., \& Fathurrochman, I. (2020). Covid-19: Political Cooperation and Ritual Modification of Religious Worship Through Large-Scale Social Restrictions. Systematic Reviews in Pharmacy, 11(12), 644-648.

Khasanah, U., Kristiawan, M., \&Tobari.(2019). The Implementation of Principals' Academic Supervision In Improving Teachers'

Professionalism in the State Primary Schools.International Journal of Scientific \& Technology Research, 8(8).

Kristiawan, M., \& Elnanda,D. (2017). The Implementation of Authentic Assessment in Cultural History of Islamic Subject. Al-Ta lim Journal, 24(3), 266-276.

Kristiawan, M., \&Elnanda, D. (2017). The Implementation of Authentic Assessment in Cultural History of Islamic Subject. Al-Ta lim Journal, 24(3), 266-276.

Kristiawan, M., Jumeldi, A., Ahmad, S., \&Asvio, N. (2016). The Implementation Of Affective Assessment For Islamic Education In High School 1 Pariangan. Research Journal of Social Sciences, 9(4), 1-8.

Kusen, K., Hidayat, R., Fathurrochman, I., \& Hamengkubuwono, H. (2019). Strategi Kepala Sekolah Dan Implementasinya Dalam Peningkatan Kompetensi Guru. Idaarab: Jurnal Manajemen Pendidikan, 3(2), 175-193.

OECD. (2001). Designs for Learning: 55 Exemplary Educational Facilities. Paris: OECD.

Risdianto, E., Wachidi, Riyanto, Alexon, Fathurrochman, I., Kusen. (2021). Blended Learning Model Based on Massive Open Online Courses (MOOCs) Assisted by Augmented Reality (BMA) Model as the 
Electronic Learning Media in the Pandemic Covid-19. Al- Ishlah: Jurnal Pendidikan, 13 (1), 228-241

Ristianti, D. H., Danim, S., Winarto, H., \& Dharmayana, I. W. (2019). The Development Of Group Counselling Assessment Instruments. International Journal of Scientific \& Technology Research, 8(10), 267-272. Retrieved from http://www.ijstr.org/paperreferences.php?ref=IJSTR-1019-23814

Salwa., Kristiawan, M., \& Lian, B. (2019). The Effect of Academic Qualification, Work Experience and Work Motivation towards Primary School Principal Performance. International Journal of Scientific \& Technology Research, 8(8).

Sukirman, H.(1999). Administrasidan Supervisi Pendidikan. Yogyakarta: FIP UNY.

Tim Dosen Jurusan Administrasi Pendidikan. (2002). Pengelolaan Pendidikan. UNY.

Wahyuningrum. (2000). Manajemen Fasilitas Pendidikan. Yogyakarta: AP FIP UNY.

Wandasari, Y., Kristiawan, M., \& Arafat, Y. (2019). Policy Evaluation of School's Literacy Movement on Improving Discipline of State High School Students. International Journal of Scientific \& Technology Research, 8(4). 
80 | Tadbir : Jurnal Studi Manajemen Pendidikan, Vol. 5, No. 1, 2021

This page belongs to the TADBIR : Jurnal Studi Manajemen Pendidikan

TADBIR : Jurnal Studi Manajemen Pendidikan Vol. 5, No.1, Mei 2021

IAIN Curup - Bengkulu | p-ISSN 2580-3581; e-ISSN 2580-5037 